\title{
ANTECEDENTS OF EMPLOYEE LOYALTY IN AN EMERGING ECONOMY: THE MALAYSIAN MULTIMEDIA SUPER CORRIDOR
}

\author{
PETER ROSS AND YUNUS ALI*
}

This paper examines the information and communication technology (ICT) sector of a developing 'middle income country', Malaysia. The development of the Malaysian ICT sector was state-led through the creation of the Multimedia Super Corridor, which formed an important plank in the government's stated goal of achieving developed country status by 2020. Earlier research on ICT workers has tended to focus on ICT clusters in developed countries, such as Silicon Valley in the United States. This paper in contrast seeks to draw out significant factors that impact on ICT worker loyalty in a developing middleincome country. It compares and contrasts these findings with prior research on ICT workers in developed economies. The research finds similarities, but also significant differences in the Malaysian context. In contrast to the experience of developed countries, this study found a greater propensity for Malaysian ICT firms to employ their workers on a full-time basis.

\section{AN INCREASING BODY OF RESEARCH HAS FOCUSED ON THE} MANAGEMENT OF information and communication technology (ICT) workers and associated public policy issues, such as, human capital development, the off-shoring of ICT services and the protection of intellectual property rights. (Benner 2002, Holm, Lahteenmaki, Salmela and Suomi 2002, Hyde 2003, McKeown, Veenhof and Corman 2008, Niederman and Ferratt 2006, Tremblay 2003, Valgaeren 2008). Whilst most of this work has focused on these issues in the context of developed countries, little attention has been paid to these issues in developing countries (Aubert 2005, Harbi, Amamou and Anderson

\footnotetext{
* Peter Ross is in the Department of International Business and Asian Studies at Griffith University, Nathan, QLD, and Yunus Ali is in the School of Business at Monash University Malaysia, Sunway, Malaysia. The authors gratefully acknowledge the assistance and support provided by Mr Cheah and Mr RamaChandran of PIKOM, the National ICT Association of Malaysia. Correspondence to: p.ross@griffith.edu.au.
} 
2009, Kuppusamy 2009: 3). Aubert suggests that much of this research on innovation and technological development in developed countries may not be applicable in a developing country context, as the latter face different challenges (2005: 6). Further, while much of the media 'now take it as an article of faith that ICTs . . can be significant enablers of positive change in the developing world', there is a lack of empirical support for this perspective' (Chew, Vigneswara Ilavarasan and Levy 2010). This paper aims to help fill this gap by examining human resource management (HRM) issues and challenges associated with the Malaysian government's strategies to develop a nascent high-tech industrial sector; the need to develop human capital is a key characteristic of the sector (Harbi et al 2009: 465).

The issue of employee loyalty is a topical one for the ICT industry given the supposed labour market volatility associated with the sector, linked to the use of subcontractors, combined with the ease with which large amounts of digitised data may now be copied and taken from firms (Benner 2002, Clinton 1997, Hyde 2003). These labour market characteristics have created a number of HRM challenges, including labour force retention and intellectual property (IP) rights concerns. The ability for high skilled Malaysian ICT workers to relocate to higher paying jobs in nearby countries, such as Singapore or Australia, gives further impetus to the need to analyse factors that impact on employee loyalty and retention. Further, given the Malaysian government's ambitious project to turn the country into a regional ICT hub as part of its Vision 2020 plan (MSC Malaysia 2008, ISIS 2002), it is important to examine similarities and context related differences between ICT labour markets in developed countries and this emerging Asian economy.

This study is exploratory, and is based on qualitative and quantitative research conducted in the Malaysian ICT industry between 2008 and 2009. The paper begins by examining the background to the development of the Malaysian ICT sector before reviewing the literature on ICT worker management and employee loyalty. The dearth of literature examining this sector in developing and emerging country contexts required us to take a more exploratory approach to better understand the industry and enable us to design the quantitative phase of this study. Therefore, the paper synthesises the literature with qualitative interview data to form a number of hypotheses for empirical testing. It analyses and discusses the research data and concludes by considering the implications of these findings.

\section{Malaysian Multimedia Super Corridor (MSC)}

Malaysia achieved impressive economic growth in the post-World War II era, achieving average annual growth rates in excess of seven percent over a 25 year period (CGD 2008, Schuman 2010). Much of this was export-led 
economic growth. Despite this relative success, the available research suggests that Malaysia has entered a 'middle-income trap', whereby it has attempted to maintain export competitiveness through limiting wage increases, but has been increasingly undercut by relatively cheaper labour from countries such as China and Vietnam (CGD 2008, Yusuf and Nabeshima 2009, Schuman 2010). The World Bank further advises that Malaysia needs to shift from 'low-cost to highvalue' economic development strategies (2010: 61). This situation had in part led to the Malaysian government's Multimedia Super Corridor (MSC) strategy that aimed to shift the economy further up the value-added path by creating high-technology industrial centres with associated enhanced labour market skills; technological capability being an important factor in raising labour productivity (Carayannis and Sagi 2002: 518, Harbi et al 2009).

The MSC strategy was very much government-led, being a vision of former Malaysian Prime Minister, Dr Mahathir Mohamed. Government incentives to attract ICT related foreign direct investment (FDI) - and associated knowledge transfer - included 10 year tax breaks for overseas firms and the provision of modern ICT infrastructure. This included the development of 'cybercities': large industrial parks/suburbs that provide the underlying infrastructure for ICT firms (MSC 2008a). The aim was to replicate the success of high-technology clusters in regions such as Silicon Valley, and develop these areas into high-technology clusters that would support entrepreneurship and innovation (Benner 2002, Hyde 2003). The original and largest cyber city is Cyberjaya, which is located outside the Malaysian capital, Kuala Lumpur, and administered by the Multimedia Development Corporation (MDeC); a quasi-government body (Evers, Nordin and Nienkemper 2010).

Further inducements for investors in the ICT sector included the awarding of 'MSC status' to qualifying firms. This added to their local status, particularly when tendering for government related jobs. $\mathrm{MDeC}$ managers further advised that MSC status made it relatively easy for MNC firms to apply to bring in overseas workers. However MSC firm managers advised that the relative ease of bringing in overseas ICT workers had been tempered by rising wages in the Indian and Sri Lankan ICT sectors - some of Malaysia's mains sources of overseas ICT labour. Yahya and Kaur concur that the relative decrease in wages differentials had made it more difficult for Malaysian firms to attract ICT professionals from India (2008: 29). Further, Malaysian firms had to compete for this overseas talent with Singapore, where wages for ICT workers were on average 120 percent higher than those paid in Malaysia (Yahya and Kaur 2008: 27). This further emphasises the need for Malaysian firms to train and retain local ICT workers, given the increasing difficulties in supplementing local skill shortages with overseas workers (Yahya and Kaur 2008: 29).

The MSC strategy remains on-going. It includes developing and networking more cybercities and smaller cyber centres throughout Malaysia; its vision is 
to transform Malaysia into a 'Knowledge-based Economy and Society' by the year 2020. However, the Malaysian economy was negatively affected by the Asian financial crisis in the late 1990s, while economic growth has still not returned to pre-crisis levels (Koshy, Habib, Chapman, Kong, Chin, Loo, Ho and Foong 2010). More recently the economy was further negatively affected by the Global Financial Crisis when it recorded the highest negative growth in 2009 of the middle-income countries of East Asia (World Bank 2010: 11).

Jarman and Chopra (2008) suggest that despite the Malaysian government's continued monetary investment and support, the MSC has not yet achieved its aim in developing a leading ICT hub for research and development. Rather it has been more successful in developing lower value-added business support services, which are less likely to boost overall incomes across society (Jarman and Chopra 2008). Harbi et al found similar patterns in their study of the Tunisian ICT sector, which continued to play a 'subordinate role in the global value chain' (2009: 465). A recent World Bank report also advised that 'Malaysia has had mixed success in facilitating technology transfers from multinational companies and in multiplying domestic linkages with them' (2010: 12). Therefore, while the MSC strategy has had some notable successes, its faces significant future challenges.

The MSC strategy is further complicated by Malaysia's multicultural society. Malaysia's main ethnic groups include Malays and indigenous peoples (known as Bumiputeras), who represent 62 percent of the Malaysian population, Chinese (24 percent) and Indians (7 percent) (CIA 2011). The ethnic Chinese minority tend to dominate business and economic power across Malaysia, while the ethnic Malay majority play the foremost role in government. This situation has 'fostered nationality based affirmative economic policies to assist the Malays' (Bhaskaran and Sukumaran 2007). As outlined above, the MSC strategy is government initiated and predominantly run by Malays all interviews conducted by the authors with MSC representatives were with ethnic Malays. However most of our interviews with the managers of local ICT firms were conducted with ethnic Chinese. While we acknowledge that these are sensitive local political issues, and emphasise that our quantitative data does not address ethnic issues, it is nonetheless salient to note that anecdotal feedback from interviewees indicated that this ethnic divide may impact at times on the operations of local ICT firm owners. Comments from a number of interviewees, for example, supported earlier research which suggested that Malaysian ICT firms needed to hire ethnic Malay (Bumiputera) ICT workers in order to compete for government contracts (Yahya and Kaur 2008: 28). Interviewees also advised that many ethnic Chinese ICT professionals leave Malaysia to work overseas where they can command higher salaries; such factors may exacerbate local ICT labour market skill shortages. 


\section{Research Background}

The rapid growth of the ICT sector, supported by the accelerated development of computing capacity and internet delivered goods and services, has seen a steadily expanding body of research examining this sector and its workforce (Benner 2002, Hyde 2003, McKeown, Veenhof and Corman 2008, Niederman and Ferratt 2006, Ross 2009, Tremblay 2003, Valgaeren 2008). A number of HRM issues emerged as key themes in this research, including the issue of relatively high labour turnover rates, the apparent prevalence of fixed-term contract workers and challenges concerning the protection of intellectual property (IP) rights - all factors that impact on employee loyalty. As outlined above, much of this earlier research has focused on developed countries, particularly those located in North America and Europe (see Benner 2002, Holm et al 2002, Hyde 2003, Tremblay 2003, Valgaeren 2008), while the extant literature and associated research on ICT worker management in developing countries, in contrast, is more limited (Aubert 2005, Harbi et al 2009, Kuppusamy 2009: 3). Further, much of the HRM-related research examining the ICT sector in developing countries has focused on lower value-added outsourced services, such as call centres (Budhwar, Varma, Singh and Dhar 2006, Levy 2005, Russell 2009, Russell and Thite 2009). In one of the few studies of the Malaysian ICT sector Mat Nor (2006) examined a range of knowledge management issues. However, her definition of 'knowledge workers' is very broad, which limits the applicability of these finding to ICT workers specifically. The scarcity of published empirical evidence on higher skilled ICT workers in Malaysia and/or other emerging economies, therefore, highlights the need for more exploratory research in this area, as these countries seek to develop high-tech industries.

What, then, do we mean when we speak of 'ICT workers', especially given that workers across many sectors now use ICT tools to perform their job? The Malaysian government's definition of a 'knowledge worker', which includes both ICT graduates and anyone with a university degree (Mat Nor 2007), was considered too general for this study. Rather this study utilises the OECD (2006: 216) definition, which divides ICT workers into three categories:

(i) ICT specialists, who have the ability to develop, operate and maintain ICT systems. ICTs constitute the main part of their job;

(ii) advanced users, consisting of competent users of advanced, and often sector-specific, software tools. ICTs are not the main job but a tool; and

(iii) basic users, who include competent users of generic tools (e.g. Microsoft Word, Excel, Outlook, PowerPoint) needed for the information society, e-government and working life.

This study focuses on the first of these three categories - 'ICT specialists' for whom ICTs constitute the main part of their job description. This more 
constrained definition better highlights the type of workers being researched, as opposed to the more generic concept of the 'knowledge worker'. In making this distinction, we nonetheless accept however that some ICT workers 'may not fit neatly into any one particular category, making the line in the sand fuzzy' (Niederman and Ferratt 2006: xii).

The paper builds on previous research by providing a comprehensive 'mixed methods' approach that includes qualitative and quantitative data analysis of Malaysian ICT workers. This allows for greater research depth and flexibility including an ability to examine the 'complex interactions of culture, institutions, societal norms and government regulations' within the Malaysian context (Kiessling and Harvey 2005). Organisations were initially contacted by telephone using publicly available sources that listed the contact details of Malaysian ICT firms. Interviews were then organised with HRM managers who were willing to take part in this research; where a firm did not have a specific HRM management role, the general manager was interviewed. This resulted in qualitative data collection from 21 interviews with middle-level or senior executives from Malaysian ICT related government, semi-government, and commercial organisations. These included different Multimedia Development Corporation (MDEC) managers, representatives of the Penang Skills Development Corporation (PSDC) and the Software Consortium of Penang (SCoPe), and managers of Malaysian based subsidiaries of foreign MNCs, Malaysian MNCs and Malaysian SMEs in the ICT industry.

Interviews were semi-structured with a list of questions developed from previous research into the ICT sector being used as the basis for each interview (see Benner 2002, Clinton 1997, Hyde 2003, Tremblay 2003, Valgaeren 2008). However interviewees were given every opportunity to discuss in further detail any areas that were of particular concern to them, including local Malaysian-specific issues. The interviews were based on an estimated time frame of 60 minutes each, however, most lasted 90 minutes or longer. All of the interviewees were conducted in English, as most middle managers and above in the Malaysian ICT sector speak English fluently. Confidentiality guarantees and associated university ethical requirements meant that interviewee names and specific firms could not be stated in this paper. The qualitative data was further supported by direct observations and discussions made by the authors. These included observations of Malaysian ICT employees at work and general informal discussions with local Malaysian academics, business people and international expatriates. Secondary data included company reports, previous literature and studies, and other available sources.

The interview data was examined to draw out recurring comments and themes that were pertinent to this analysis. While comments such as these provide insights that provide interesting grounds for conjecture, qualitative research is limited by the difficulty in generalising its findings (Daymon and 
Holloway 2002). Therefore in line with our mixed methods approach, and the exploratory nature of the research, the above qualitative data was used to assist in the development of a number of hypotheses for empirical testing. A survey based on ICT worker and employee loyalty and commitment literature (Benner 2002, Clinton 1997, Hyde 2003, Lee, Allen, Meyer and Rhee 2001, Meyer and Allen 1997, Nogueras 2006, Rothausen, 1994, Meyer, Stanley, Herscovitch and Topolnytsky 2002, Tremblay 2003, Valgaeren 2008) and the interview data was further conducted to investigate different aspects of the Malaysian ICT labour market, including worker loyalty and commitment to their organisations. The survey in part tested whether the themes elicited during the qualitative data collection stage reflected the views of the broader population. Potential identified factors that could impact on Malaysian ICT managers' perceptions of worker loyalty included job security, the ICT labour market, employment contracts, training practices, flexible working conditions, compensation and external networking. The development of our hypotheses and quantitative data research methods and analysis are outlined below.

\section{ICT Workers and Loyalty}

This section synthesises the qualitative interview data with the literature on ICT workers and employee loyalty in order to develop a number of hypotheses. It should be noted that this analysis does not attempt to provide a full examination of the broad ranging general extant literature on employee loyalty and commitment, which has often 'treated the employees as homogeneous and ignored the nature of the work undertaken by employees' (Benson and Brown 2007: 122). Rather, it focuses on ICT sector specific issues that may impact on ICT worker loyalty in the Malaysian context.

Coughlan (2005) discusses some of the problems inherent in defining the term 'employee loyalty' and suggests that many contemporary researchers tend to use the term synonymously with employee commitment (see Meyer and Allen 1997, O'Reilly and Chatman 1986). Coughlan, however, considers that employee loyalty has a more moral basis than does commitment. This includes on-going ethical behaviour on the part of the employee, whereby workers consider the appropriateness of their intentions before acting. This may include an implicit understanding not to bring harm to the firm and/or others within the firm (Coughlan 2005). For example, protecting an ICT firm's IP rights. Porter defines employee loyalty as 'affection for, and attachment to the organisation; a sense of belongingness manifested as a wish to stay' (Porter 1974 in Shepherd and Mathews 2000: 558). Loyal employees are also more likely to 'trust the organisation and management to do the right thing' (Robbins, Millett, Cacioppe and Waters-Marsh 1998: 182), while Shepherd and Mathews view loyalty as 'a strong desire to maintain membership in 
the employing organisation, or the aspiration to remain in the employ of the organisation' (2000: 557). Boroff and Lewin go so far as to suggest that loyal workers will remain within a firm and 'suffer in silence' even when they believe they have been treated unfairly (1999: 50).

Employee loyalty has, therefore, been linked to trust, moral obligations and a desire on the part of the worker to remain employed within a particular firm. Yet this conception of the term would seem at odds with much of the literature on ICT workers, which suggests that this sector is typified by volatile labour markets. For example, researchers suggest that turnover rates in some sections of the Indian ICT sector are as high as 50 to 75 percent (Machado and Kourakos 2004: 8). Such relatively high turnover rates in part reflect the sectors' perceived suitability for project workers operating on fixed-term and/or short-term contracts (Benner 2002, Clinton 1997, Hyde 2003, Tremblay 2003, Valgaeren 2008). Valgaeren (2008), for example, examines the development of independent 'nomadic' ICT workers in the Flemish IT sector, while Hyde (2003) discusses this issue within the context of 'high velocity' labour markets that characterise Silicon Valley. Similar patterns have been found in the telecommunication sector, with next generation Telco networks being increasingly built and maintained by external contractors (Ross 2009). While such employment arrangements arguably allow employers greater numerical flexibility, the decreased job security brought about by such atypical employment arrangements could be expected to lead to decreased employee loyalty to the firm (Robinson, Kraatz and Rousseau 1994, Davis-Blake, Broschak and George 2003).

Feedback from interviewees in the Malaysian ICT sector supported the view that full-time ICT workers were more loyal to their firms than outsourced or fixed-term workers. The qualitative data further implied that subcontractors were used to a lesser extent by Malaysian ICT firms than the extant literature on ICT workers in developed countries suggested. This response was particularly apparent in small to medium sized enterprises (SMEs), which represents the predominate form of indigenous Malaysian ICT firm (Yew 2009: 4-5). Among these firms, managers stated that they employed their ICT workers on a fulltime basis because full-time workers were more loyal and less likely to leave the firm. One interviewee, for example, advised that their firm only employed full-time workers because:

... outsourced workers don't feel part of the company. They have less loyalty to the firm and the firm has no loyalty to them.

Such employees would therefore have little identification or emotional attachment - i.e. 'affective commitment' - to the firm (Meyer and Allen 1997).

A particular problem for local Malaysian owned SMEs was the ability for MNCs to pay higher wages, allowing the latter to potentially poach high-skilled 
workers from SMEs. Offering full-time employment was therefore a strategy that Malaysian SMEs used to help counter head-hunting from other firms. Some managers also advised that SMEs had an advantage over MNCs in that their full-time ICT workers often created and administered most of their projects themselves, as opposed to being just another cog in the machinery of a large firm. These workers consequently felt a high degree of ownership and pride in the results of their completed projects. Given the above apparent link between loyalty and full-time work our first hypothesis states:

Hypothesis 1: In-house ICT full-time workers are more loyal to their firms than outsourced and/or subcontracted ICT workers.

Intuitively, employee loyalty, including the desire on the part of the employee to remain at the firm, will be further influenced by the 'perceived ease of movement' with which a worker can gain employment elsewhere (Mitchell, Holtom, Lee, Sablynski and Erez 2001: 1107); i.e., the availability, or otherwise, of alternative employment opportunities (Allen 1990: 4, Meyer and Allen 1997). Debrah (1994), for example, discusses this issue in relation to recruitment and retention problems in the Singaporean hotel industry during a period of acute labour shortages in this sector. The Singaporean HRM managers, who were interviewed during this study, advised that the external labour market often dictated their staffing and recruitment practices (Debrah 1994). Hunt and Rasmussen (2007) further examine the inverse relationship between retention rates and tight labour markets in their study of New Zealand call centres. Similarly, during interviews Malaysian ICT firm managers advised that staff retention rates decreased during the 'dot.com boom', when many ICT firms were actively hiring ICT staff, and increased during the 'dot.com bust', ${ }^{1}$ when ICT firms were laying-off staff. Interviewees further suggested that the negative publicity surrounding the layoffs of ICT workers during the 'dot.com bust' continued to deter students from enrolling in ICT related tertiary studies. For example, despite the Malaysian government's efforts to develop a larger ICT workforce, ICT tertiary enrolments decreased from 2004 to 2007 (Kunalan 2010). PIKOM, the peak national ICT industry group, forecasts that Malaysia will face a shortfall of 40,000 knowledge workers across the ICT industry by 2012 (PIKOM 2008, 2008a). In the Malaysian context, falling ICT graduate enrolments juxtaposed with an expanding ICT sector, could be expected to create a tight labour market for skilled ICT workers, with a concomitant increase in ICT worker turnover. Our second hypothesis therefore states:

1. The 'dot com boom' spanned the period 1996 to 2000, while the 'dot com bust' began in 2000 and lasted until around 2003/2004 (Callahan 2003). 
Hypothesis 2: ICT workers will exhibit lower levels of loyalty in a tight ICT sector labour market, where the demand for ICT workers exceeds supply.

The qualitative phase of this research found ICT graduate skills and training needs to be important issues in Malaysian ICT industry. Further, tight labour markets may be compounded by low graduate skill levels. In this regard, Malaysian managers were generally underwhelmed by the quality of their ICT graduate employees; no interviewees rated graduate technical skills highly. For example, one HR manager defined Malaysian ICT graduates as having 'level one basic technical skills; reasonable but not great'. This was a typical response. Another respondent blamed the gap between ICT graduate skills and industry expectations in part on the Malaysian education system where 'students are taught to answer questions, not to ask questions'. The implication was that this teaching approach stifled initiative and innovation.

Virtually all of the managers who were interviewed advised that they provided staff with some form of regular training. However, because many local Malaysian ICT firms are SMEs with limited resources (Hashim 2006), this was often limited to on-the-job training, with more experienced ICT workers acting as mentors to less experienced recruits. In contrast, more expensive off-the job external training was generally conducted by SMEs on an ad hoc basis, being limited to specific training requirements that might arise from time to time for specific jobs. The managers advised that their employees were generally keen to gain more training, which they linked to improved employee morale and commitment. One interviewee for example worked in a firm that had previously been a subsidiary of a large Japanese MNC that engaged in extensive regular training. This manager advised that 'loyalty disappeared' when the Japanese firm sold the subsidiary, because the new owners stopped many of these training programs. The interviewee responses therefore suggested that there was a positive link between training and perceptions of employee loyalty in the Malaysian ICT sector.

The available literature on training and its impact on worker loyalty and retention, however, is somewhat mixed. De Vos and Maganck (2009: 50) cite staff training and development as the number one retention strategy employed by HR practitioners in their study. However, while the provision of training and development opportunities may build relational capital between employers and their employees and improve worker loyalty, this is predicated on firms concurrently providing career paths within the firm (De Vos and Maganck 2009, Robinson et al 1994: 139, Hytter 2007: 69). The latter would seem at odds with the atypical employment practices and volatile ICT labour markets described above (Benner 2002, Hyde 2003, Valgaeren 2008). However the above qualitative data provided by the Malaysian interviewees suggested that in contrast to 
earlier research on the ICT sector in developed countries, many Malaysian ICT workers, especially those employed by SMEs, were in fact engaged on a fulltime basis. Malaysian SMEs also often operate in niche areas, as they cannot compete head to head against large firms in more general sectors. Such firms may be more likely to train their ICT workers in firm-specific skills, as these are more difficult to transfer out of the firm; sometimes called 'non-portable' training (see Williamson 1991, Mitchell et al 2001: 1107). Therefore, within the Malaysian context, given the apparent widespread use of full-time workers in the Malaysian ICT sector combined with the prevalence of local SMEs competing in niche areas our third hypothesis states:

Hypothesis 3: The provision of training by ICT firms is positively related to ICT worker loyalty.

Staff loyalty and retention also impacts on the management of IP rights. The very nature of the ICT sector means that much of the value-added and/ or competitive advantage of an ICT firm resides in the heads of its workers (Awad and Ghaziri 2003, Jashapara 2004, SamGnanakkan 2010). When ICT workers leave a firm they take this knowledge with them. This knowledge may then be used to assist competitor firms and/or the former employee may become a future competitor themselves (Williamson 1991). Because of this issue, most interviewees advised that they made their workers sign some form of legal employment contract regarding the use of the firms' IP. In many instances this included a proviso stating that the worker could not leave and work for a competitor firm within a specified period of time. Discussions with MSC representatives also suggested that the use of such post-employment restraints in employment contracts was widespread across the Malaysian ICT sector. Interestingly, many interviewees advised that enforcing these employment contracts would be costly and often difficult to prove. Some were also unsure of the legality of their employment contracts. Therefore many of these managers advised that attempting to enforce the contracts would not generally be economically worthwhile. Rather, the contracts appeared to be an expectation of how they expected their ICT workers to behave. Nevertheless, requiring employees to sign legal contracts suggests a lack of trust and a possible breach of the psychological contract (De Vos and Meganck 2009, Robinson et al 1994) between managers and their ICT workers. Our fourth hypothesis therefore states:

Hypothesis 4: The use of employment contracts to prevent ICT workers from leaving and working for competitor firm is negatively related to ICT employee loyalty. 
Other traits exhibited by ICT workers also impact on IP right issues. For example, researchers suggest that ICT workers tend to engage in extensive external networking with fellow ICT colleagues, where they swap information and ideas (Benner 2002, Hyde 2003). Similarly it has also been suggested that 'knowledge workers' exhibit low organisational commitment as they may be more loyal to their profession and fellow ICT colleagues than to their employers (Benson and George 2007, 126, Chattopadhyay 2005). Therefore, while external networking may assist in the development and cross pollination of ideas (Hyde 2003), it also opens the door to the potential loss of a firm's IP to the external colleagues of their workers. Further, anecdotal evidence from interviewees suggested that ICT workers networked with external colleagues to explore their own market potential outside the organisation and exchange information on job opportunities in competing organisations. Therefore, the managers' who were interviewed generally saw the networking behaviour of their ICT employees as being negatively related to employee loyalty. Our next hypothesis therefore states:

\section{Hypothesis 5: ICT employee networking behaviour will be negatively related to employee loyalty.}

The Malaysian ICT sector is further characterised by the youth of much of its workforce (Khoo 2009). It is a relatively new sector in Malaysia and anecdotal evidence from the interviewees further suggested that it is often staffed by younger workers and managers, including the so called 'Gen Y' the generation born after 1978 (Khoo 2009: 138). Oliver advises that for the 'Gen Y' employee 'workplace flexibility and genuine work-life balance . . . are essential requirements' (Oliver 2006:62). This premise is supported by Khoo, who suggests that Malaysian ICT firms need to build flexible work schedules into their organisations, as this strategy will help to retain 'Gen Y' workers (2009: 139). Further, the maximisation of innovation and creativity may require more flexible and informal approaches to employee management than the traditional fixed eight hour work day within the firm. Tales of Silicon Valley senior managers in firms such as Google and Apple turning up for work in t-shirts and sneakers are commonplace (Benner 2002, Hyde 2003). Researchers have also found a positive relationship between flexible working conditions, employee job satisfaction and retention in the ICT sector (Ahuja 2007, Mantyla 2006: 67-68). This suggests that more flexible and informal working conditions should be associated with higher degrees of ICT employee job satisfaction and loyalty. Our sixth hypothesis therefore states:

Hypothesis 6: $\quad$ Flexible working arrangements will be positively linked to ICT worker loyalty. 
Along with non-monetary rewards (see Robinson et al 1994), such as training and working conditions discussed above, monetary rewards will also obviously impact on ICT worker loyalty to the firm (De Vos and Meganck 2009, SamGnanakkan 2010: 46-47). While Malaysian ICT worker compensation has been increasing above the inflation rate, starting salaries for new graduates remain quite low. Malaysian unions are also relatively weak (see Benson and Zhu 2008) with union density at 7.45 percent of the workforce in 2008 (Rose, Kumar and Ramasamy 2011). Section nine of the Malaysian Industrial Relations Act (MIRA) also excludes workers from joining unions if they are managerial or executive workers and/or if they are engaged in work that is confidential in nature (MTUC 2010: 6), which potentially excludes many ICT workers. For example, a representative from the National Union of Telekoms Employees advised that while the former government Telco monopoly, Telekom Malaysia had an overall union density rate of around 70 percent, the above section of the MIRA effectively excluded most of Telekom Malaysia's ICT workers from the union. Most interviewees advised that wage rates for the ICT sector were governed by the 'going market rate' and their responses to what they were paying their ICT workers were quite consistent for similar levels of skills and experience (see Table 1).

Some managers however advised that the requirement for firm-specific skills could drive up wages for companies operating in niche markets, as these skills were not so freely available in the labour market. The interview data suggested that larger firms, including MNCs, also generally provided further bonuses on top of the above base rates of between one to two months pay per year, along with other benefits such as health insurance for workers and their families. The latter appeared to be more appreciated by older workers who were more likely to be married with children. Younger workers in contrast were more interested in the cash component of their remuneration.

Table 1. Base ICT wage rates in Malaysia, 2008

\begin{tabular}{ll}
\hline Experience & Malaysian Ringgit $($ RM) per month \\
\hline New graduate to 1 year & RM1,800 to RM2,200 \\
2 to 3 years & RM3,000 to RM4,000 \\
4 to 5 years ${ }^{1}$ & RM4,000 to RM5,000+ \\
\hline
\end{tabular}

Source: Interviews 2008

1. After five years ICT employees' wages tend to stagnate unless they then move up into a management position.

A problem with paying the 'market rate' is that, non-monetary rewards aside, employees are likely to go and work for another firm that offers employment at 
above the market rate (De Vos and Meganck 2009, SamGnanakkan 2010: 46). Younger Malaysian ICT workers would appear to be especially susceptible to this; as outlined above, they begin their careers on relatively low labour market entry salaries. Interviewees also suggested that 'headhunting' was also relatively widespread across the Malaysian ICT sector. This suggests that simply paying at the 'market' rate is negatively linked to ICT worker loyalty. Our final hypothesis therefore states:

Hypothesis 7: Employing ICT workers at the market rate will be negatively linked to ICT worker loyalty.

\section{Research Methods, Analysis and Findings}

As indicated earlier, this research used a mixed methods approach (Creswell 2009). Justification for using qualitative research in this exploratory study and the method used for the qualitative data collection were outlined above. This section provides an overview of the quantitative data collection method and statistical analyses used for the empirical testing of the hypotheses developed in the last section. It also outlines the research findings. Cross-sectional quantitative survey research has several strengths and plays an important role in management research in generalising findings for the target population and contributing to theory building and theory-testing (Rindfleisch, Malter, Ganesan and Moorman 2008).

We collected data from managers in the Malaysian ICT sector through a mail survey and telephone interviews using a unique survey instrument developed from the literature and qualitative data as outlined above. A random sample of 250 ICT firms were selected from the published list of ICT firms in Malaysia and a survey pack including explanatory statement, survey questionnaire and postage paid envelope was sent to the general manager with a request to pass it to the HR manager in the firm. The mail survey was supplemented by Malaysia's largest ICT business group, PIKOM, who commissioned an independent external firm to survey a randomly selected sample out of 1410 PIKOM members by telephone. As with the qualitative data, HRM managers were interviewed in most instances, while the general manager was interviewed where a firm was too small to have a separate HR department.

A total of 395 cases (361 completed telephone surveys from PIKOM member firms and the return of 34 completed mail surveys from non-PIKOM member firms) were found usable for analysis. The participating firms were sorted into seven MSC categories: Creative Multimedia, Hardware design, Manufacture and Distribution; Internet Based Businesses and Telecoms; 
Software Development; Shared Services and Outsourcing; and Support Services. However, our analysis for this paper focused on the three ICT firm categories of software, multimedia and internet based businesses where ICT workers are involved in the development, operation and maintenance of ICT systems as the main part of their job. These workers therefore accorded with our above ICT worker definition (OECD 2006: 216). This reduced our total usable sample to 146 which is large enough to satisfy the variable to case ratio in a multivariate model (Tabachnic and Fidell 2007) with four composite and four single item variables.

\section{Measurement of Variables}

The dependent and independent variables in this study were measured by a combination of multiple and single item scales mostly drawn from the extant literature as well as developed for the study based on the exploratory part of this research. A structured survey instrument was designed using a 7 point Likert scale to capture the subjective assessment of the responding managers, with 1 equalling strongly disagree and 7 equalling strongly agree. Multi-item measures were used for the Dependent Variable (DV) Loyalty (5 items) and three Independent Variables (IVs) - ICT Employee Training (6 items), Networking (4 items) and Flexible Working Conditions (6 items). All items were initially tested for internal consistency and structure using Factor Analysis (FA) and the reliability of each measurement scale was later tested using Cronbach Alpha.

\section{Statistical Analysis}

The data structure of all multi-items measures were initially tested using factor analysis with varimax rotation. All 21 items used for the measurement of the dependent and independent variables were tested together in a single solution to determine whether all items were loaded in their expected factor. Sixteen items loaded in four factors with acceptable factor loadings (range from .62 to .90) and explained 66 percent of the variances in the data. Four items were excluded either for their low loading or high cross loading, and one item for forming a separate factor of its own. The reliability of the measurement scales was tested and two multi-item scales exceeded the conventional 0.7 Cronbach's alpha level (reported in Table 2), which indicated acceptable reliability of the measures. Composite index (arithmetic average of items) of all multi-item scales were then used in multiple regression analysis to test our hypotheses. 
Table 2. Factor Solution of Measurement Scales

Measurement Items

Factor

Loading

Employee Loyalty (Standardized Cronbach Alpha: 0.76)

ICT workers are more loyal to their own careers than to the firms that they

work for.

ICT workers are more loyal to their own profession than to the firms that they work for.

ICT workers will leave to work for any other firm that offers them more money.

I am concerned that ICT workers may leave our firm and take this

knowledge with them to a competitor firm.

ICT Employee Training (Standardized Cronbach Alpha: 0.77)

Our firm regularly engages in technical skills training for our ICT workers.

Our firm regularly engages in English language training for our

ICT workers.

Our firm regularly engages in communications skills training for our ICT workers.

Most of our training programs are conducted in-house with our own trainers.

ICT Employee Networking (Standardized Cronbach Alpha: 0.62)

I am concerned that external networking between ICT workers may lead to

the loss of knowledge to ICT workers in competitor firms

ICT workers regularly network in order to look for jobs in other firms.

ICT workers regularly network in order to find out what other ICT workers are being paid.

ICT Flexible Working Conditions (Standardized Cronbach Alpha: 0.65)

Our ICT workers operate within semi-independent teams.

Our firm has introduced flexible working hours for our ICT workers.

Our firm is considering introducing flexible working hours for its

ICT workers.

Our firm allows our ICT employees to work from home.

Our firm is considering introducing policies that would allow our ICT

employees to work from home.

\section{Malaysian ICT Labour Market}

It is easy to find and recruit qualified ICT workers.

\section{Full-Time Workers}

In-house full-time workers are more loyal to the firm than outsourced or contracted ICT workers.

\section{Employment Contract}

Our firm uses written employment contracts to prevent our ICT workers from working for competitor firms if they resign from our company.

\section{Compensation}

Pay rates for our ICT workers are determined by the 'going market rate' (i.e. what everyone else is paying). 
Bivariate correlations between variables were calculated to check the presence of possible multi-collinearity between variables (Table 3). None of these correlation coefficients exceeded 0.4 , suggesting multi-collinearity was unlikely to affect confidence in our estimation using regression analysis. All assumptions associated with ordinary least squares regression were tested, including univariate and multivariate normality, and all test results satisfied the required acceptable level.

Table 3. Correlation matrix

\begin{tabular}{|c|c|c|c|c|c|c|c|c|c|c|}
\hline Variables & Mean & $\begin{array}{l}\text { Std } \\
\text { Dev }\end{array}$ & 1 & 2 & 3 & 4 & 5 & 6 & 7 & 8 \\
\hline $\begin{array}{l}\text { 1. ICT Labour } \\
\text { Market }\end{array}$ & 3.66 & 1.37 & 1 & & & & & & & \\
\hline $\begin{array}{l}\text { 2. Full time } \\
\text { worker }\end{array}$ & 3.49 & 1.28 & .130 & 1 & & & & & & \\
\hline 3. IP Right & 3.88 & 1.63 & -.086 & -.019 & 1 & & & & & \\
\hline $\begin{array}{l}\text { 4. Compensa- } \\
\text { tion }\end{array}$ & 4.56 & 1.23 & .002 & .040 & $.288 * * 1$ & & & & & \\
\hline $\begin{array}{c}\text { 5. Employee } \\
\text { Training }\end{array}$ & 4.49 & 1.15 & .077 & .007 & $.224 * *$ & $.214 * * 1$ & & & & \\
\hline $\begin{array}{l}\text { 6. Employee } \\
\text { Network }\end{array}$ & 4.50 & 0.97 & -.027 & -.048 & $.254 * *$ & $.397 * *$ & $.439 * * 1$ & & & \\
\hline $\begin{array}{l}\text { 7. Working } \\
\text { Condition }\end{array}$ & 3.80 & 1.00 & -.020 & .122 & $.166^{*}$ & $.302 * *$ & $.272 * *$ & $.218^{* *}$ & & \\
\hline $\begin{array}{l}\text { 8. Employee } \\
\text { Loyalty }\end{array}$ & 3.23 & 1.02 & $.447 * *$ & $* .287 * *$ & $-.239 * *$ & $-.306 * *$ & .027 & $-.219^{* *}$ & -.008 & 1 \\
\hline
\end{tabular}

$\mathrm{N}=146$. Two-tailed Significance Levels: $* *=0.01 ;$ and $*=0.05$

Results of the multiple regression model are presented in Table 4. The model fit statistics $($ F-value $=13.819)$ suggests a good model fit, while the model explains more than 40 percent of the variance in workers' loyalty - 45 percent for the sample and 41 percent adjusted for the population. Coefficient beta values for four of the variables are highly significant and that of another variable is significant with a 93 percent confidence level.

\section{Discussion}

The regression model reported in Table 4 supports Hypothesis 1, which predicted that in-house full-time ICT workers would be perceived as more loyal to their firms than outsourced and/or subcontracted ICT workers, with a high confidence level of 99 percent. This supports both interview data and previous research linking atypical and contract work to reduced worker loyalty to their organisations. 
Table 4. Regression Results: ICT worker loyalty to their organisation

\begin{tabular}{lcc}
\hline Dependent variables & Beta co-efficient & (t-statistic) \\
\hline ICT Labour Market & $0.366^{* *}$ & $(5.291)$ \\
Full time worker & $0.227^{* *}$ & $(3.451)$ \\
Employment Contract & -0.093 & $(-1.315)$ \\
Compensation & $-0.217^{*}$ & $(-2.936)$ \\
Employee Training & 0.129 & $(1.820)$ \\
Employee Network & $-0.301^{* *}$ & $(-4.129)$ \\
Flexible Working Conditions & 0.057 & $(0.817)$ \\
\hline$R$-square & 0.447 & \\
Adjusted $R$-square & 0.414 & \\
$F$-Value & $13.819^{* * *}$ & \\
\hline
\end{tabular}

* Significant at the $\mathrm{p}<0.05$ level, ** significant at the $\mathrm{p}<0.01$ level

It further lends support to interviewee statements that suggested Malaysian ICT firms were more likely to employ workers on a full-time rather than atypical basis. The result shows even stronger support for Hypothesis 2, which linked ICT worker loyalty to the state of the labour market. Intuitively this finding makes sense, as slack labour markets, where the supply of ICT workers exceeds demand, suggest that workers are more likely to remain in their current jobs as there are fewer alternatives. In contrast, tight labour markets, typified by ICT worker shortages, make it easier for workers to gain employment elsewhere. During interviews with Malaysian managers tight labour markets were also linked to 'headhunting' across the sector. The descriptive statistics outlined in Table 3 also show the mean response to the question 'It is easy to find and recruit qualified ICT workers' was a relatively low 3.66 (on a scale of 1 to 7), which supports PIKOM's statements concerning skill shortages across the sector.

The model provides mixed support for the expected impact of non-monetary rewards on worker loyalty. For example, it provides only weak support for Hypothesis 3, where we expected employee training would be linked to increased ICT worker loyalty. As discussed above, the literature on training levels and its links to employee loyalty is mixed, and the hypothesis was developed in part on anecdotal evidence from interviewees including the apparent prevalence of Malaysian firms employing workers on a full-time basis across the sector. The results however do not provide any strong support for this factor being linked to employee loyalty, at least from the perspective of Malaysian ICT managers. The lack of strong support to this hypothesis may further indicate that some participating organisations, especially SMEs, might have lost some of their trained ICT workers to other organisations. This may have negatively affected those managers' assessment of the benefits of training to their organisation. These results also provide support for the contention 
that providing training and employee development alone cannot retain ICT workers unless they are integrated into a career path that allows for further job development and career enhancement (see De Vos and Meganck 2009: 58).

The model provides no support for Hypothesis 6, which linked flexible working arrangements to greater ICT worker loyalty. This result may be influenced by the prevailing cultural norms of Malaysia, which include relatively high degrees of power distance and formality, along with relatively low levels of uncertainty avoidance (Hofstede 2011). High power distance is linked to the use of full titles, such as Mr, Mrs, Miss and Sir which is the norm within Malaysian work environments. Low uncertainty avoidance is linked to workers feeling uncomfortable in unstructured situations, which again would militate against the introduction of more-flexible/less-structured working conditions (Hofstede 2011). When discussing this issue, one interviewee advised that 'Malaysia is not ready for this yet!' Other interviewees advised that while they were open to the idea of introducing more flexible working arrangements, they encountered strong resistance from upper level management when they tried to broach this subject. Such cultural norms, however, may work against developing the creativity required for a more innovative ICT sector, along with the work/life balance being sought by Gen Y workers. Yusoff (2011: 9) concurs that Malaysia's traditional hierarchical and high power distance cultural norms may not be suitable for modern business environments.

The model provided support for the expected impact of monetary rewards on worker loyalty. Hypothesis 7 predicted that 'paying the market rate' would negatively impact on ICT worker loyalty. The regression results found this relationship to be highly significant. This provides some interesting grounds for conjecture, as it infers that managers perceive that their ICT workers will leave them to work for any other firm that offers them above market rate compensation. Under this scenario SMEs have little hope of stopping their ICT staff from being poached by larger firms, including MNCs, as the latter have the resources to pay higher wages. This is especially pertinent in relation to trained and enthusiastic ICT workers, who regularly network with their professional peers.

We consider two possible explanations of this result. In light of the above rejection of hypotheses 3 and 6, one interpretation is that this result simply reflects a relatively tight local labour market where ICT workers value monetary over non-monetary rewards. However, given that the survey was conducted with Malaysian managers, as opposed to directly with their ICT workers, a second interpretation is that it may reflect local management perceptions that their ICT workers are more focused on monetary rather than non-monetary rewards, which in turn reflects traditional Malaysian employment practices. Further, management and employee views on why workers leave or remain with firms may differ (De Vos and Meganck 2009). This suggests that further research is required to ascertain what ICT workers themselves actually think about non-monetary versus 
monetary rewards. Given that SMEs cannot compete head to head with larger firms on monetary compensation alone, a wage focused retention strategy alone, will have limited success. Therefore the ability of non-monetary rewards, such as flexible working conditions, to retain skilled workers in a relatively tight labour market becomes a potentially important issue.

The model found some interesting results regarding ICT workers' external networking behaviour. In this regard the results provide strong support for Hypothesis 5, with a highly significant regression coefficient. We expected HR managers to have a negative perception of external networking amongst their ICT workers in relation to its impact on employee loyalty and the result is significant, with very high confidence level. This is an interesting finding as it supports previous research in other countries which suggests that ICT workers may be more loyal to their colleagues and profession than their organisations (George and Chattopadhyay 2005). This external networking culture may therefore impact on a firm's ability to retain their highly trained ICT workers and control their IP rights. The relatively high mean value for the composite measure (4.55) further suggests that many managers perceive that their ICT workers regularly network with outside colleagues to find other jobs and to find out what other firms are paying. These behaviours tend to have negative impacts on staff retention. If ICT workers are regularly networking to find out what other firms are paying then this also supports the view that ICT firms may need to investigate the use of non-monetary rewards as a strategy to improve staff loyalty and retention, or face the prospect that workers will simply leave to work for any firm that offers them more money.

An examination of our remaining hypothesis shows no support for Hypothesis 4, which linked the use of employment contracts to lower perceptions of worker loyalty. Despite the anecdotal evidence that employment contracts are widely used across the Malaysian ICT sector and often written with the intention of preventing ICT workers from leaving to work for competitor firms and taking the firms IP rights with them, the mean response to this question was lower than expected (3.9 on a scale of 1 to 7 ). The result may also reflect the general feedback from interviewees that the use of these contracts was more of a general expectation on how they expected their workers to behave, rather than as a legal document that they would consider using to prosecute former employees in court. Further, the rapidly changing nature of the ICT industry meant that 'new' technology and processes often become redundant relatively quickly. Many interviewees also made a distinction between newer and/or fixedterm employees and experienced workers and/or managers. They advised that short-term project workers and new workers generally had limited knowledge of specific processes and/or parts of a project. Managers in contrast had more detailed comprehensive knowledge of entire projects and/or firm processes and therefore were the employees that they were most concerned about with regards to the potential loss of firm-specific knowledge. 


\section{Conclusion}

This research outlined some points of difference between the Malaysian ICT sector and other ICT sectors around the world. This included an apparent greater use of full-time workers and a relatively lower use of outsourced workers than other countries, such as the US. Both the qualitative and quantitative data linked this to management perceptions that full-time workers were more loyal than outsourced workers. SME managers in particular appeared to use the offer of full-time work - and associated greater job security - as a strategy to help reduce staff turnover rates. This suggests that Malaysian ICT workers enjoy a greater degree of job security than their compatriots in other countries. Worker turnover in this context therefore appears to be more employee rather employer instigated, with the external labour market dictating the ease with which workers can find jobs elsewhere. Relatively tight labour markets also suggest supply constraints that have the potential to constrain the continued development of the Malaysian ICT sector and to increase 'headhunting' type recruitment tactics. Global competition for ICT skills along with rising wages in the Indian ICT sector are also reducing the ability of Malaysian ICT firms to supplement local labour shortages with skilled overseas workers.

Malaysian ICT firms also appeared reluctant to introduce the types of flexible work practices reminiscent of ICT sectors elsewhere. Given the relative youth of its ICT workforce and an acknowledgement that younger workers need to be managed differently than older workers, it is perhaps surprising that this remains the case, although cultural issues - including relatively high power distance and uncertainty avoidance factors - may also play a part here (Hofstede 2011). This is, therefore, an area for potential further research to ascertain what younger ICT workers themselves, as opposed to their managers, think about the introduction of innovative HRM practices, such as flexible working hours and working from home arrangements, as this may improve retention rates amongst this group of employees. As noted above, the current emphasis on monetary as opposed to non-monetary rewards for workers may put SMEs at a disadvantage compared with MNCs, as the former cannot generally compete on wages, but may be able to offer their workers more flexible and attractive working conditions. Further, potential Malaysian ICT graduates themselves must see the sector as having the potential of providing them with their career expectations, including longterm employability within the sector, good working conditions and reasonable remuneration. The dearth of collective bargaining in the sector also suggests a potential role for government in setting better entry level wages to attract more younger workers into the sector.

The research also found some areas of similarity between the Malaysian ICT sector and research on ICT worker behaviour in other countries, including the prevalence of external networking between ICT workers and their colleagues. 
This finding supports prior research on the sector (Benner 2002, Hyde 2003), while the growth of social networking sites such as 'Facebook' and 'Twitter' is likely to further exacerbate this trend. This study showed this worker trait as having a negative influence on worker loyalty. This included management concerns over employees using these external networks to find other jobs and the possible loss of IP rights. However legal strategies to address this issue, such as the use of employment contracts, were not as widespread as the study first envisaged. Rather, it appears that this is a problem that Malaysian managers acknowledge but tend to 'live with' as part of operating in the sector. As outlined above, the rapidly changing nature of the sector - including the speed with which information is widely disseminated - also means that IP rights may become redundant relatively quickly. Interviewees also advised that in some instances managerial skills and process were more important to their firms than more technically focused IP rights.

The subject of IP rights also creates public policy issues. While governments typically legislate to protect IP rights, Hyde (2003) attributes much of the success of Silicon Valley in California to the 'cross pollination' of ideas made possible by a high velocity labour market. He implies that the regular movement of ICT workers between firms allows them to exchange ideas which in turn provides the catalyst for much of the innovation that underpins Silicon Valley's success (Hyde 2003:3-23). Hyde (2003) postulates that current trade secret laws - which seek to protect a firm's IP rights - may actually hinder rather than help the very innovation they are supposed to support, because they may slow down and/or limit the diffusion of knowledge. This has possible implications for countries such as Malaysia that are attempting to foster innovative ICT clusters. Relatively high worker turnover in this context therefore may provide some positive externalities with regards the industry sector in general; however, it still provides challenges for the management of IP property rights for individual Malaysian firms.

To conclude, this research elicited some interesting findings regarding Malaysian managers' perceptions of ICT worker loyalty. These finding provided some support for prior studies in the sector in other countries along with more Malaysian specific responses that differed from other international experiences. This study points to the need to for further research in this area, in particular the need to research ICT worker perceptions to ascertain the degree to which worker views and aspirations correlate with the views of management. This could then lead to potentially improved strategies to address HR issues - including worker loyalty - in the Malaysian ICT sector.

\section{References}

Agarwal, R and Ferratt, T W (2006) 'Validation of Human Resource Strategies in Information Technology.' In F. Niederman and T.W. Ferratt, eds., IT Workers: Human 
Capital Issues in a Knowledge-Based Environment, Greenwich, Conn.: Information Age Publishing.

Allen, N. (1990) 'The Measurement and Antecedents of Affective, Continuance and Normative Commitment to the Organisation.' Journal of Occupational Psychology, 63: 1-18.

Aubert, J-E (2005) 'Promoting Innovation in Developing Countries: A Conceptual Framework.' World Bank Policy Research Working Paper 3554 (April 2005).

Awad, E M and Ghaziri, H M (2003) Knowledge Management. New Jersey: Pearson/Prentice Hall.

Ahuja, M K, Chudoba, K M, Kacmar, C J, McKnight, D H and George, J F (2007) 'ICT

Road Warriors: Balancing Work-Family Conflict, Job Autonomy, and Work Overload to Mitigate Turnover Intentions.' MIS Quarterly, 31 (1): 1-17.

Benner, C (2002) Work in the New Economy. Flexible Labor Markets in Silicon Valley. Oxford: Blackwell Publishing.

Benson, J and Brown, M (2007) 'Knowledge Workers: What Keeps Them Committed; What Turns Them Away.' Work Employment \& Society, 21 (1): 121-41.

Benson J and Zhu Y eds., (2008) Trade Unions in Asia: An Economic and Sociological Analysis. London/New York: Routledge.

Bhaskaran, S and Sukumaran, N (2007) 'National Culture, Business Culture and Management Practices: Consequential Relationships?' Cross Cultural Management: An International Journal, 14 (1): 54-67.

Boroff, K E and Lewin, D (1997) 'Loyalty, Voice, and Intent to Exit a Union Firm: A Conceptual and Empirical Analysis.' Industrial and Labor Relations Review, 51 (1): 50-63.

Budhwar, P S, Varma, A, Singh, V and Dhar, R (2006) 'HRM Systems of Indian Call Centres: An Exploratory Study.' International Journal of Human Resource Management, 17 (5): 881-897.

Callahan, G (2003) 'Does Austrian Business Cycle Theory Help Explain the Dot-Com Boom and Bust?' Quarterly Journal of Austrian Economics, 6 (2): 67-98.

Carayannis, E G and Sagi, J (2002) 'Exploiting Opportunities of the New Economy: Developing Nations in Support of the ICT Industry.' Technovation, 22: 517-524.

CGD (Commission on Growth and Development.) 2008. The Growth Report: Strategies for Sustained Growth and Inclusive Development. Washington: The World Bank.

Chew, H E, Vigneswara Ilavarasan, P and Levy, M R (2010) 'The Economic Impact of Information and Communication Technologies (ICTs) on Microenterprises in the Context of Development.' The Electronic Journal on Information Systems in Developing Countries, 44 (4): 1-19.

CIA (Central Intelligence Agency) (2011) 'Malaysia: Ethic Groups', World FactBook, CIA. <https://www.cia.gov/library/publications/the-world-factbook/geos/my.html>. (last accessed March 22, 2011).

Clinton, A (1997) 'Flexible Labor: Restructuring the American Workforce.' Monthly Labor Review, 120 (8): 3-27.

Coughlan, R (2005) 'Employee Loyalty as Adherence to Shared Moral Values.' Journal of Managerial Issues (April 1, 2005). <http://www.allbusiness.com/human-resources/ employee-development-employee-ethics/990016-1.html>.

Crestwell, J W (2009) Research Design: Qualitative, Quantitative and Mixed Method Approaches, Thousand Oaks: Sage Publications. 
Davis-Blake, A, Broschak, J P and George, E (2003) 'Happy Together? How Using Nonstandard Workers Affects Exit, Voice, and Loyalty among Standard Employees.' The Academy of Management Journal, 46 (4): 475-485.

Daymon, C and Holloway, I (2002) Qualitative Research Methods in Public Relations and Marketing Communications. London: Routledge.

Debrah, Y A (1994) 'Management of Operative Staff in a Labour-scarce Economy: The Views of Human Resource Managers in the Hotel Industry in Singapore.' Asia Pacific Journal of Human Resources, 32 (1): 41-60.

De Vos, A and Maganck, A (2009) What HR Managers do Versus what Employees Value: Exploring Both Parties' Views on Retention Management from a Psychological Contract Perspective.' Personnel Review, 38 (1): 45-60.

Dif, M (2004) 'Vocational Identities in Change in the Telecommunications Sector.' Career Development International, 9 (3): 305-321.

Evers, H-D, Nordin, R and Nienkemper, P (2010) 'Knowledge Cluster Formation in Peninsular Malaysia: The Emergence of an Epistemic Landscape.' (October 12, 2010). Social Science Research Network (SSRN). <http://ssrn.com/abstract=1691008>.

George, E and Chattopadhyay, P (2005) 'One Foot in Each Camp: The Dual Identification of Contract Workers.' Administrative Science Quarterly, 50: 68-99.

Han, N C, Ko, J, Price, J L and Muler, C W (1995) 'Organisational Commitment in South Korea', Research and Practice in Human Resource Management, 3 (1): 39-68.

Harbi, S, Amamou, M and Anderson, A (2009), 'Establishing a High-Tech Industry; The Tunisian ICT Experience.' Science Direct, 29: 465-80.

Hashim, N A (2006) 'SMEs and E-Commerce in Malaysia: An Exploratory Study of Effectiveness of Government ICT Assistance Programmes.' Proceedings of the SMEEntrepreneurship Global Conference (Bandar Sunway, Malaysia, October 17-18), Bandar Sunway: Monash University.

Hofstede, G (2011) 'Malaysia.' Geert Hofstede Cultural Dimensions. <http://www.geerthofstede.com/hofstede_malaysia.shtml >. (last accessed March 21, 2011).

Holm, J, Lahteenmaki, S, Salmela, H and Suomi, R (2002) 'Best Practices of ICT Workforce Management: A Comparable Research Initiative.' Journal of European Industrial Training, 26 (6/7): 333-341.

Hunt, V and Rasmussen, E (2007) 'Turnover and Retention in a Tight Labour Market: Reflecting on New Zealand Research.' New Zealand Journal of Employment Relations, 32 (1): 45-57.

Hyde, A (2003) Working in Silicon Valley: Economic and Legal Analysis of a High Velocity Labor Market. New York: Armonk.

Hytter, A (2007) 'Retention Strategies in France and Sweden.' The Irish Journal of Management, 28 (1): 59-80.

ISIS (Institute of Strategic and International Studies) (2002) Knowledge Based Economy: Master Plan. Kuala Lumpur, Malaysia: ISIS.

Jarman, J and Chopra, P S (2008) 'Business Services and the Knowledge Economy in Malaysia.' International Journal of Sociology and Social Policy, 28 (5/6): 193-203. Jashapara, A (2004) Knowledge Management. London: Prentice Hall.

Kiessling, T and Harvey, M (2005) 'Strategic Global Human Resource Management Research in the Twenty-First Century: An Endorsement of the Mixed-Method Research Methodology.' International Journal of Human Resource Management, 16 (1): $22-45$. 
Khoo, J (2009) 'Overcoming IT Skills Shortage Through Innovative HR Imperatives for Sustainable Organisation' in Ramachandran Ramasamy, ed. ICT Strategic Review 2009/10: Innovation the Way Forward. Kuala Lumpur, PIKOM/MOSTI: 133-140.

Koshy, S, Habib, S, Chapman, K, Kong, L, Chin, T-S, Loo, T-E, Ho, S and Foong, J (2010) 'The middle income trap.' The Star Online (January 29, 2010). <http://thestar.com.my/ news/story.asp?file=/2010/1/29/nation/5567122\&sec=nation $>$.

Kunalan, M I (2010) 'Bridging the ICT Talent Gap.' Paper presented to the National ICT Conference 2010. Innovative Malaysia: ICT Accelerating Change and Performance in Government and Business (Kuala Lumpur, 11-12 October), Kuala Lumpur: MDEC.

Kuppusamy, M, Raman, M and Lee, G (2009), 'Whose ICT Investment Matters to Economic Growth: Private or Public? The Malaysian Perspective.' The Electronic Journal on Information Systems in Developing Countries, 37/7: 1-19.

Lee, K, Allen, N J, Meyer, J P and Rhee, K-Y (2001) 'The Three-Component Model of Organisational Commitment: An Application to South Korea.' Applied Psychology, 50 (4): 596-614.

Levy, D L (2005) 'Offshoring in the New Global Political Economy.' Journal of Management Studies, 42 (3): 685-693.

Machado, V and Kourakos, G (2004) 'IT Offshore Outsourcing Practices in Canada.' Public Policy Forum, Ottawa. <http://www.ppforum.ca/sites/default/files/it_outsourcing.pdf>. (last accessed August 17, 2011).

Mat Nor, N (2006) 'Knowledge Workers and Knowledge Management: Some Descriptive Evidences on the MSC Status Companies in Malaysia.' Proceedings of the Knowledge Management International Conference and Exhibition 2006 (KMICE 2006):

Organisational and Inter-organisational Learning: Creating, Retaining, and Transferring Knowledge (Kuala Lumpur, 6-8 June), Kuala Lumpur: pp. 440-448.

Mat Nor, N. (2007) 'Understanding the contribution of human resource management in the knowledge-based economy: Some evidences on the multimedia super corridor (MSC) status companies in Malaysia.' Proceedings of the 9th International Human Resource Management Conference: Changes in Society, Changes in Organisations, and the Changing Role of HRM, Managing International Human Resources in a Complex World, (Tallinn, 12-15 June), Tallin.

McKeown, L, Veenhof, B and Corman, J (2008) 'Profiling Internet use among workers in the information and communications technologies sector.' Innovation Analysis Bulletin, 10, (1): 22.

MSC Malaysia (2007) Impact Survey 2007. Cyberjaya: MDEC.

MSC Malaysia (2008) Vision and Mission. MSC. <http://www.mscmalaysia.my/ topic/12073014710796>. (last accessed on December 20, 2008).

MSC Malaysia (2008a) MSC National Rollout. MSC._<http://www.mscmalaysia.my/ topic/12073013095558>. (last accessed on September 24, 2008).

Mantyla, S (2006) From Myths to Reality: Challenges of the HR Management in the ICT Sector. Helsinki and Turku: Tietoalat STTK and University of Turku.

Meyer, J and Allen, N J (1997) Commitment in the Workplace: Theory, Research, and Application. Thousand Oaks: Sage.

Meyer, J P, Stanley, D J, Herscovitch, L and Topolnytsky, L (2002) 'Affective, Continuance, and Normative Commitment to the Organisation: A Meta-analysis of Antecedents, Correlates, and Consequences.' Journal of Vocational Behavior, 61 (1): 20-52. 
Mitchell, T R, Holtom, B C, Lee, T W, Sablynski, C J and Erez, M (2001) 'Why People Stay: Using Job Embeddedness to Predict Voluntary Turnover.' The Academy of Management Journal, 44 (6): 1102-1121.

MTUC (Malaysian Trade Union Congress) (2010) Kongres Kesatuan Sekerja Malaysia: Review of Labour Legislations by the Ministry of Human Resources, Proposed Amendments to the Employment Act 1955, Industrial Relations Act 1967, Trade Unions Act 1959, Position paper (21 April 2010). Kuala Lumpur: MTUC.

National SME Development Council (2005) Definitions for Small and Medium Enterprises in Malaysia. Kuala Lumpur: Secretariat to National SME Development Council (June 9, 2005).

Niederman, F and Ferratt, T W (2006) IT Workers: Human Capital Issues in a KnowledgeBased Environment. Greenwich/Conn.: Information Age Publishing (IAP).

Nogueras, D J (2006) 'Occupational Commitment, Education, and Experience as a Predictor of Intent to Leave the Nursing Profession.' Nursing Economics, 24 (2): 86-93.

OECD (2006) 'ICT Skills and Employment.' OECD Information Technology Outlook 2006. Paris: OECD.

Oliver, D (2006) 'An expectation of success: The work attitudes of Generation Y.' Labour and Industry, 17 (1): 61-84.

O'Reilly, C A and Chatman, J (1986) 'Organisational Commitment and Psychological Attachment: The Effects of Compliance, Identification and Internalization on Prosocial Behavior.' Journal of Applied Psychology, 71: 492-499.

PIKOM (2008) IT Job Market in Malaysia 2008. Kuala Lumpur: PIKOM/KPMG.

PIKOM (2008a) PIKOM, the National ICT Association of Malaysia: 5 YEAR PLAN (2008-2012). Kuala Lumpur: PIKOM.

Rindfleisch, A, Malter, A J, Ganesan, S and Moorman, M (2008), 'Cross-Sectional versus Longitudinal Survey Research: Concepts, Findings and Guidelines.' Journal of Marketing Research, 45 (2): 261-279.

Robbins, S P, Millett, B, Cacioppe, R and Waters-Marsh, T (1998) Organisational Behaviour: Leading and Managing in Australia and New Zealand. Sydney: Prentice Hall.

Robinson, S L, Kraatz, M S and Rousseau, D M (1994) 'Changing Obligations and the Psychological Contract: A Longitudinal Study.' The Academy of Management Journal, 37 (1): 137-152.

Rose, R C, Kumar, N and Ramasamy, N (2011) 'Trade unions in Malaysia: perspectives of employers and employees of unionized companies.' Indian Journal of Industrial Relations, 46 (3): 384-395

Ross, P K (2009) 'New Technology and Work in the Australian Telecommunications Sector: What Role for Technicians?' Labour and Industry, 20 (1): 45-66.

Rothausen, T J (1994) 'Job satisfaction and the parent worker: The role of flexibility and rewards.' Journal of Vocational Behavior, 44 (3): 317-336.

Russell, B (2009) Smiling Down the Line: Info-Service Work in the Global Economy. Toronto: University of Toronto Press.

Russell, B and Thite, M eds., (2009) The Next Available Operator: Managing Human Resources in Indian Business Process Outsourcing Industry. New Delhi: Sage.

SamGnanakkan, S. (2010) 'Mediating Role of Organisational Commitment on HR Practices and Turnover Intention among ICT Professionals.' Journal of Management Research, 10 (1): 39-61. 
Schuman, M (2010) 'The Curious capitalist: Escaping the middle-income trap', Time.com (August 10, 2010). <http://curiouscapitalist.blogs.time.com/2010/08/10/escaping-themiddle-income-trap/?xid=rss-topstories?artId=11366? contType=blog_the_curious_ capitalist?chn=us $>$.

Shepherd, J L and Mathews, B P (2000) 'Employee Commitment: Academic vs Practitioner Perspectives.' Employee Relations, 22 (6): 555-575.

Tabachnic, B G and Fidell, L S (2007) Using Multivariate Statistics. Boston: Pearson/ Allyn and Bacon.

Tremblay, D-G (2003) 'New types of careers in the knowledge economy? Networks and boundaryless jobs as a career strategy in the ICT and multimedia sector.' Canada Research Chair on the Socio-Organisational Challenges of the Knowledge Economy: Research Note no 2003-12A. Québec: Télé-université, University of Québec.

Valgaeren, E (2008) 'Nomadic Careers in the Flemish IT-sector: Fact or Fiction?' Paper presented at the First ISA Forum of Sociology (Barcelona, 5-8 September 2008), Barcelona: International Sociological Association (ISA).

Wanous, J P, Reichers, A E and Hudy, M J (1997) 'Overall Job Satisfaction: How Good Are Single-Item Measures?' Journal of Applied Psychology, 82 (2): 247-252.

Williamson, O E (1979) 'Transaction-cost Economics: The governance of contractual relations.' Journal of Law and Economics, XXVI ( 2): 233-261.

Williamson, O E (1991), 'Strategizing, Economising, and Economic Organisation.' Strategic Management Journal, 12: 75-94.

Williamson, O E (1996) The Mechanisms of Governance. Oxford University Press, Oxford. World Bank (2010) Malaysia Economic Monitor: Growth through Innovation. Bangkok: The World Bank.

Yahya, F and Kaur, A (2008) 'Indian Skilled Workers and Professional Talent in Southeast Asia.' UNEAC Asia Papers: Special Issue Migration and Security: Political, Social and Economic Contexts of Migration, 23: 19-32.

Yew, O K (2009) 'About PIKOM: The National ICT Association of Malaysia.' in Ramachandran Ramasamy, ed. ICT Strategic Review 2009/10: Innovation the Way Forward. Kuala Lumpur, PIKOM/MOSTI: 1-12.

Yusuf, S and Nabeshima, K (2009) 'Can Malaysia Escape the Middle-Income Trap? A Strategy for Penang.' The World Bank Development Research Group, Policy Research Working Paper 4971 (June 2009). <http://econ.worldbank.org>.

Yusoff, W F W (2011) Does organisational culture influence firm performance in Malaysia?' International Journal of Multidisciplinary Research, 1 (3): 1-12. 